\title{
Implementation of Contextual Teaching and Learning Model ( CTL) to Improve Students' Learning Motivation in Grade 3 SDN Wanoja 01
}

\author{
Rodiah \\ SDN WANOJA 01 \\ rodiahyuni2@gmail.com
}

\section{Article History}

accepted 01/11/2020

\begin{abstract}
This research aims to find out the increased motivation of students in grade III SDN Wanoja 1 through ctl model in theme 3, knowing the increase in learning activities of grade III students at SDN Wanoja 1 through ctl model. This research was conducted in grade 3 of Wanoja State Elementary School 01. Data collection in this study uses test-shaped data collection techniques and with non-tests.. From all the data obtained in learning improvement activities through this class action research with the application of contextual teaching and learning approach, can be concluded as follows, the implementation of contextual approach can increase the motivation of Learning in grade 3 sdn Wanoja. This is characterized by the increasing quality of students' spirit and response in solving problems given by teachers, the increasing ability of communication and student work as well as the learning results obtained by students. These improvements include: (a) increasing student cooperation and helping students to solve problems in the learning process (b) increasing inter-student co-operation (c) increasing student involvement in the learning process, contextual learning, has given a new nuance in learning in theme 3 so that learning is more effective.
\end{abstract}

Keywords: Contextual Teaching And Learning, Learning Motivation

\begin{abstract}
Abstrak
Penelitian ini bertujuan untuk mengetahui peningkatan motivasi peserta didik di kelas III SDN Wanoja 1 melalui model CTL pada tema 3, mengetahui peningkatan aktifitas belajar peserta didik kelas III SDN Wanoja 1 melalui model CTL. Penelitian ini dilakukan di kelas 3 SD Negeri Wanoja 01. Pengumpulan data pada penelitian ini menggunakan teknik pengumpulan data berbentuk tes dan dengan non tes.. Dari seluruh data yang diperoleh dalam kegiatan perbaikan pembelajaran melalui penelitian tindakan kelas ini dengan penerapan pendekatan contextual teaching and learning,dapat diambil simpulan sebagai berikut, penerapan pendekatan kontekstual dapat meningkatkan motivasi Belajar di kelas 3 SDN Wanoja. Hal ini ditandai dengan semakin berkualitasnya semangat dan respon siswa dalam memecahkan persoalan yang diberikan guru,meningkatnya kemampuan Komunikasi dan kerjasa siswa serta hasil belajar yang diperoleh siswa. Peningkatan tersebut meliputi : (a) meningkatnya kerjasama siswa dan tolong menolong antar siswa untuk memecahkan soal dalam proses pembelajaran (b) meningkatnya kekompakan antarsiswa (c) meningkatnya keterlibatan siswa dalam proses pembelajaran, pembelajaran kontekstual, telah memberikan nuansa baru dalam pembelajaran di tema 3 sehingga pembelajaran lebih efektif.
\end{abstract}

Kata kunci: Contextual Teaching And Learning, Motivasi Belajar

Social, Humanities, and Education Studies (SHEs): Conference Series https://jurnal.uns.ac.id/shes

p-ISSN 2620-9284

e-ISSN 2620-9292 


\section{PENDAHULUAN}

PTK terdiri dari penelitian, tindakan, dan kelas. Penelitian merupakan kegiatan mencermati suatu objek dengan menggunakan aturan metodologi tertentu untuk memperoleh data dan informasi yang bermanfaat dalam meningkatkan mutu suatu hal, serta menarik minat dan penting bagi peneliti. Tindakan adalah kegiatan yang sengaja dilakukan dengan tujuan tertentu, sedangkan kelas adalah sekelompok siswa yang dalam waktu yang sama menerima pelajaran yang sama dari seorang guru (Arikunto, 2006).

Langkah-langkah Penelitian Tindakan Kelas (a) Menemukan ide awal yang menemukan gagasan yang dapat ditempuh untuk memecahkan masalah. Ide awal berupa upaya yang dapat ditempuh untuk mengatasai masalah. Dengan penerapan PTK sebenarnya peneliti mau berbuat apa. (b) Melakukan prasurvey yaitu mengetahui secara detail kondisi kelas yang akan diteliti. Hal ini tidak perlu dilakukan bagi guru yang akan meneliti kelas yang diajarnya, karena dengan mengajar tentu ia sudah sangat memahami kondisi kelas tersebut. Prasurvey dilakukan jika peneliti tidak mengajar pada kelas yang diteliti. (c) Mendiagnosis bahwa ada dugaan sementara mengenai timbulnya permasalahan di dalam kelas. Diagnosis dilakukan oleh peneliti yang tidak biasa mengajar kelas yang akan diteliti. Hasil diagnosis akan menentukan perancangan strategi pembelajaran, media materi dan lain-lain yang terkait dalam kegiatan belajar mengajar. (d) Menentukan perencanaan yang meliputi perencanaan berkaitan dengan rancangan keseluruhan aspek dalam PTK dan rencana khusus yang barkaitan dengan rancangan siklus per siklus. Hal-hal yang direncanakan kurang lebih sama dengan apabila guru menyiapkan suatu kegiatan belajar mengajar. (e) Implementasi tindakan yaitu realisasi dari suatu tindakan yang sudah direncanakan meliputi strategi yang akan digunakan, materi yang akan disampaikan dan sebagainya. (f) Pengamatan yaitu observasi dan monitoring yang dapat dilakukan sendiri oleh peneliti mapun kolaborator. Monitoring merupakan bagian dari fungsi meneliti dalam PTK. Peran monitoring adalah untuk mengenali dan mengevaluasi perkembangan yang terjadi akibat tindakan yaitu mengenali apakah pelaksanaan tindakan sesuai dengan rencana tindakan dan apakah telah terjadi peningkatan denganadanyan tindakan. Teknik yang dilakukan dapat berupa pengamatan dengan pedoman, tes, catatan lapangan, analisis dokumen, portofolio, angket, wawancara, perekaman, dan sosiometri. (g) Refleksi yaitu upaya evaluasi yang dilakukan oleh kolaborator dan partisipan yang terkait dengan PTK yang dilaksanakan. Berdasarkan refleksi kemudian dilakukan perbaikan tindakan ( siklus berikutnya). Belajar adalah suatu perubahan tingkah laku sebagai hasil dari pengalaman, belajar bukanlah menghafalkan fakta-fakta yang terlepas-lepas melainkan mengaitkan konsep-konsep yang telah ada dalam struktur kognitif.

Belajar dapat diartikan sebagai proses mental yang terjadi dalam diri seseoang dan melibatkan kegiatan berfikir yang terjadi melalui interaksi aktir dengan lingkungan ( penglam belajar ), sehingga terjadi perubhan tingkah laku yang positif. Belajar adalah proses mengkonstruksikan pengetahuan dari abstraksi pengalaman baik alami maupun masnusiawi. Proses kontruksi itu dilakukan secara pribadi dan sosial. Beberapa faktor seperti pengalaman, pengetahuan yang telah dimiliki, kemampuan kognitif dan lingkungan berpengaruh terhadap prestasi belajar. Kelompok belajar dianggap sangat membantu belajar karena mengandung beberapa unsur yang berguna menantang pemikiran dan meningkatkan harga diri seseorang.

Dengan demikian belajar bukan hanya tingkah laku yang nampak, tetapi terutama adalah proses yang terjadi secara internal di dalam diri individu dalam usahanya memperoleh hubungan baru yang berupa reaksi dan perangsang. Belajar 
akan membawa suatu perubahan yang tidak hanya berkaitan dengan penambahan ilmu pengetahuan, tetapinjuga bentuk kecakapan, keterampilan, sikap, pengertian, hartga diri, dan minat.

Dari definisi tersebut dapat disimpulkan bahwa belajar adalah perubahan tingkah laku yang diperoleh karena adanya usaha yang disengaja yang berupa pengalaman.

Menurut Danim dalam Putra (2007) motivasi diartikan sebagai kekuatan, dorongan, kebutuhan, semangat, tekanan, atau mekanisme psikologi yang mendorong seseorang atas sekelompok orang untuk mencapai prestasi tertentu sesuai dengan apa yang ia kehendaki. Dalam arti kognitif, motivasi diasumsikan sebagai aktivitas individu untuk menentukan kerangka dasar tujuan dan penentuan perilaku untuk mencapai tujuan itu. Sedangkan dalam arti afeksi motivasi bermakna sikap dan nilai dasar yang dianut seseorang atau sekelompok orang untuk bertindak atau tidak bertindak.

Motivasi dan belajar merupakan dua hal yang saling mempengaruhi. Belajar adalah perubahan tingkah laku secara relatif permanen dan secara potensial terjadi sebagai hasil dari praktik atau penguatan yang dilandasi tujuan untuk mencapai tujuan tertentu (Putra, 2007).

Dari pendapat para ahli dapat disimpulkan bahwa motivasi belajar adalah suatu dorongan atau kekuatan yang timbul dan tumbuh dari dalam maupun dari luar pada diri seseorang yang disebabkan seseorang itu mempunyai suatu keinginan yang kuat, merasa senang, dan semangat untuk belajar dalam rangka untuk dapat mencapai tujuan yang dikehendaki.

Contextual Teaching and Learning adalah sebuah proses pendidikan yang bertujuan menolong para peserta didik melihat makna di dalam materi akademik yang mereka pelajari dengan cara menghubungkan subjek-subjek akademikdengan konteks dalam kehidupan keseharian mereka, yaitu dengan konteks keadaan pribadi, sosial, dan budaya mereka (Elaine. 2009:67).

Pembelajaran kontekstual atau Contextual Teaching and Learning (CTL) merupakan konsep yang membantu guru mengaitkan antara materi yang diajarkan dengan situasi dunia nyata dan mendorong peserta didik membuat hubungan antara pengetahuan yang dimilikinya dengan penerapannya dalam kehidupan mereka sebagai anggota keluarga dan masayarakat. Pembelajaran kontekstual merupakan prosedur pendidikan yang bertujuan membantu peserta didik memahami makna bahan pelajaran yang mereka pelajari dengan cara menghubungkannya dengan konteks kehidupan mereka sendiri dalam lingkungan sosial dan budaya masayarakat (Supriyono, 2009:79).

Ada tujuh indikator pembelajaran kontekstual sehingga bisa dibedakan dengan pendekatan lainnya yaitu : (a) Modeling (pemusatan perhatian, motivasi, penyampaian kompetensi-tujuan, pengarahan-petunjuk, rambu-rambu, contoh). (b) Questioning (eksplorasi, membimbing-menuntun, mengarahkan, mengembangkan, evaluasi, inkuiri, generalisasi). (c) learning community (seluruh peserta didik partisipatif dalam belajar kelompok atau individual, mencoba, mengerjakan). (d) Inquiry (identifikasi, investigasi, hipotesis, generalisasi, menemukan). (e) Constructivism (membangun pemahaman sendiri, mengkonstruksi konsep-aturan, analisis-sintesis). (f) Reflection (reviu, rangkuman, tindak lanjut). (g) Authentic assesment (penilaian selama proses dan sesudah pembelajaran) (Suyatno. 2009:57). 
Berdasarkan Center for Occupational Research and Development (CORD) penerapan strategi pembelajaran kontekstual digambarkan sebagai berikut : (a) Relating, belajar dikaitkan dengan konteks pengalaman kehidupan nyata. (b) Experiencing, belajar adalah kegiatan mengalami peserta didik berproses secara aktif dengan hal yang dipelajari dan berupaya melakukan eksplorasi terhadap hal yang dikaji, berusaha menemukan dan menciptakan hal baru dari apa yang dipelajarinya. (c) Applying, belajar menekankan pada proses mendemonstrasikan pengetahuan yang dimiliki dalam konteks dan pemanfaatannya. (d) Cooperating, belajar merupakan proses kolaboratif dan kooperatif melalui belajar berkelompok, komunikasi interpersonal atau hubungan intersubjektif. (e) Transferring, belajar menekankan pada terwujudnya kemampuan memanfaatkan pengetahuan dalam situasi atau konteks baru (Supriyono, 2009:84 )

\section{METODE}

Penelitian ini dilakukan di kelas 3 SD Negeri Wanoja 01 Korwilcam Salem yaitu di kecamatan Salem tepatnya berada di Jalan Sukmawati No. 23 Desa Wanoja, Letaknya berada di daerah pedesaan yang jauh dari kota kecamatan dan Kabupaten. Subyek penelitian ini adalah peserta didik kelas 3 SD Negeri Wanoja 01 yang berjumlah 16 orang. Terdiri dari 5 peserta didik laki-laki dan 11 peserta didik perempuan. Pengumpulan data pada penelitian ini menggunakan teknik pengumpulan data berbentuk tes dan dengan non tes. Untuk pengumpulan data berbentuk tes menggunakan tes tertulis sedangkan non tes menggunakan observasi/pengamatan dengan melibatkan teman sejawat. Alat pengumpulan data dalam penelitian ini menggunakan instrumen butir soal tes tertulis untuk teknik tes, sedangkan untuk teknik non tes menggunakan lembar observasi dan assessment.

Observasi sebagai alat evaluasi banyak digunakan untuk menilai tingkah laku individu atau proses terjadinya sesuatu kegiatan yang dapat diamati, baik dalam situasi yang sebenarnya, maupun dalam situasi buatan. Asesment sebagai alat penilaian. Untuk mengukur sejauh mana siswa mengikuti pembelajaran dengan aktif sehingga dapat dibuktikan dengan hasil penilaian di akhir pembelajaran dengan mengerjakan tes formatif.

\section{HASIL DAN PEMBAHASAN}

Berdasarkan penelitian yang telah dilakukan di SD N Wanoja 01 diperoleh hasil sebagai berikut: Sebelum peneliti menggunakan model pembelajaran Contextual Teaching and Learning (CTL) guru hanya menjelaskan materi dipapan tulis dan peserta didik mendengarkan kemudian disuruh memahami materi pelajaran yang telah disampaikan guru. Disini guru tidak memberikan kesempatan kepada peserta didik utuk terlibat secara aktif dan langsung dalam proses pembelajaran akibatnya banyak peserta didik yang yang kurang bersemangat didalam mengikuti kegiatan proses pembelajaran dan tidak sedikit diantara peserta didik yang diam hanya duduk mendengarkan ceramah dari guru sehingga berdampak pada rendahnya motivasi belajar peserta didik serta rendahnya nilai hasil tes dalam kegiatan proses pembelajaran di kelas. 
Hal tersebut dapat terlihat pada tabel keaktifan peserta didik hasil pengamatan yang dilakukan peneliti sebagai guru kelas sebelum dilakukan tindakan penelitian dengan penerapan contextual teaching and learning. Dari 16 peserta didik kelas I SD Negeri Wanoja 01 tahun pelajaran 2020/2021 keaktifan peserta didik hanya mencapai 40\% saja.

\section{Tabel 4.1 Data keaktifan peserta didik pra siklus}

\begin{tabular}{|c|l|c|c|}
\hline No & Pembelajaran & $\begin{array}{l}\text { Keaktifan peserta } \\
\text { didik }\end{array}$ & Persentase \\
\hline 1 & Aktif & 4 & $25 \%$ \\
\hline 2 & Kurang Aktif & 7 & $43,75 \%$ \\
\hline 3 & Tidak Aktif & 5 & $31,25 \%$ \\
\hline
\end{tabular}

Dari tabel diatas, data keaktifan peserta didik pada proses pembelajaran sebelum dilaksanakan tindakan atau pra siklus jika disajikan dalam bentuk grafik akan tampak seperti berikut ini:

Rendahnya motivasi belajar berdampak pada rendahnya keaktifan peserta didik dalam kegiatan pembelajaran yang juga menyebabkan rendahnya hasil evaluasi belajar peserta didik.

Dari data diatas, tampak jelas bahwa hasil belajar peserta didik masih sangat rendah. Nilai rata-rata hasil belajar baru mencapai 60 dengan persentase ketuntasan belajar $44 \%$.hasil itu masih belum mencapai target yang ditetapkan sebagai batas ketuntasan klasikal yaitu sebesar $56 \%$ sehingga untuk mencapai tingkat ketuntasan belajar perlu diadakan perbaikan pembelajaran. Berdasarkan pelaksanaan perbaikan pembelajaran siklus I, data yang diperoleh dari hasil analisis terhadap hasil tes formatif pertemuan 1 menunjukkan adanya peningkatan prestasi belajar peserta didik. Nilai rata-rata kelas pada pertemuan ke 1 menjadi 68,44 dengan ketuntasan belajar $62,5 \%$ dan pertemuan ke 2 yaitu 72,81 dengan ketuntasan belajar $75 \%$. Itu menunjukkan peningkatan dari data pra siklus dengan nilai rata-rata 60 dengan ketuntasan belajar $44 \%$. Data tersebut di atas dapat disajikan dalam bentuk diagram batang sebagai berikut :

\section{Hasil Tes Formatif Siklus 1}

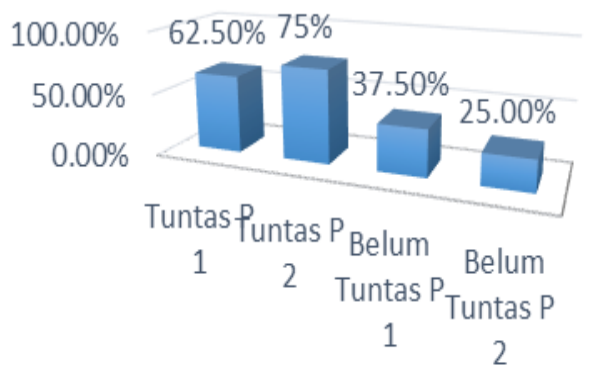




\section{Gambar 4.3 Grafik Nilai Hasil Belajar Siklus I}

Berdasarkan pengamatan, guru sudah dapat mengelola pembelajaran dengan baik. Ini ditunjukkan hasil rata-rata skor pada lembar observasi aktifitas peserta didik mengikuti pembelajaran mencapai 7,7. Jika kualitatifkan menjadi nilai B. Berarti ratarata peserta didik telah mengikuti pembelajaran dengan baik.

Namun demikian, walaupun telah terjadi peningkatan baik dalam hal motivasi belajar maupun tingkat ketuntasan, tetapi peningkatan itu belum mencapai target yang direncanakan sehingga pembelajaran masih perlu diperbaiki lagi. Oleh sebab itu penulis akan melanjutkan perbaikan pembelajaran pada siklus II. Berdasarkan pelaksanaan perbaikan pembelajaran siklus I, data yang diperoleh dari hasil analisis terhadap hasil tes formatif pertemuan 1 menunjukkan adanya peningkatan prestasi belajar peserta didik.

Nilai rata-rata kelas pada pertemuan ke 1 menjadi 73.75 dengan ketuntasan belajar $81 \%$ dan pertemuan ke 2 yaitu 81,88 dengan ketuntasan belajar $94 \%$. Itu menunjukkan peningkatan dari data siklus 1 dengan nilai rata-rata kelas pada pertemuan ke 1 menjadi 68,44 dengan ketuntasan belajar 62,5\% dan pertemuan ke 2 yaitu 72,81 dengan ketuntasan belajar $75 \%$. Itu menunjukkan peningkatan dari data pra siklus dengan nilai rata-rata 60 dengan ketuntasan belajar 44\%. Dari data tersebut di atas dapat disajikan dalam bentuk diagram batang sebagai berikut :

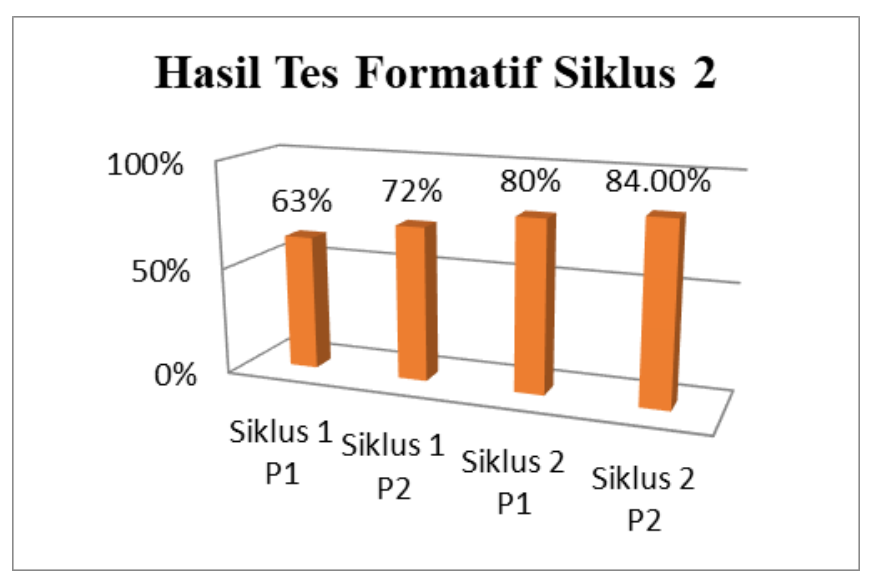

\section{Gambar 4.4 Grafik Nilai Hasil Belajar Siklus II}

Berdasarkan data pada siklus II, dari 16 peserta didik 15 orang (94\%) sudah mencapai KKM dan hanya $1(0,06 \%)$ peserta didik yang belum tuntas. Walaupun masih ada satu peserta didik yang belum tuntas, namun ketuntasan belajar yang telah mencapai $94 \%$ sudah melampaui batas ketuntasan klasikal yang di targetkan sebesar $85 \%$. Oleh sebab itu penelitian siklus II ini dinyatakan sudah berhasil. meskipun sudah berhasil ketuntasan peneliti perlu melakukan penelitian sampai siklus III karena motivasi siswa masih belum maksimal.

Berdasarkan pelaksanaan perbaikan pembelajaran siklus III, data yang diperoleh dari hasil analisis terhadap hasil tes formatif pertemuan 1 menunjukkan adanya peningkatan prestasi belajar peserta didik. Nilai rata-rata kelas pada pertemuan ke 1 menjadi 82,50 dengan ketuntasan belajar 94\% dan pertemuan ke 2 yaitu 83,13 dengan ketuntasan belajar $94 \%$. Hasil tersebut menunjukkan peningkatan dari data 
siklus II, meskipun untuk ketuntasan tetap karena siswa tersebut setelah di telaah latar belakang keluarganya serta riwayat di kelas sebelumnya memang mempunyai IQ di bawah rata-rata, tetapi jika dilihat dari rata-rata nilai terjadi peningkatan untuk rata-rata siklus II yaitu pertemuan ke 173,75 dan pertemuan ke 2 81,88. Dari penelitian data hasil evaluasi siswa disajikan diagram batang sebagai berikut :

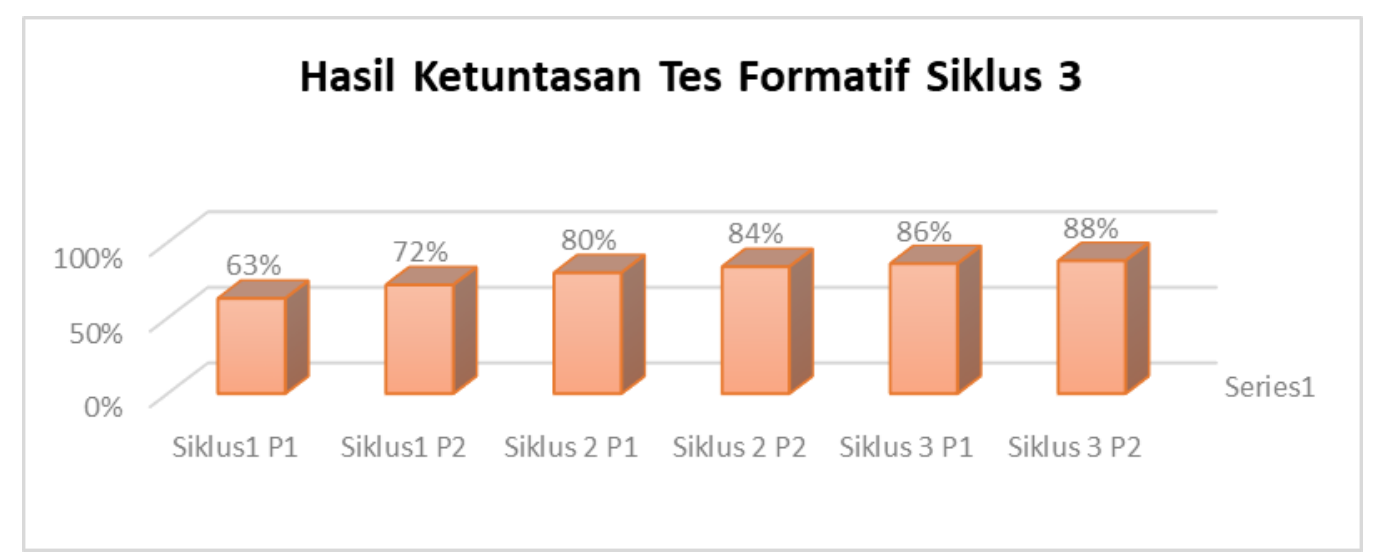

Gambar 4.4 Grafik Hasil Ketuntasan Tes Formatif Siklus III

Berdasarkan pengamatan, guru sudah dapat mengelola pembelajaran dengan baik. Ini ditunjukkan hasil rata-rata skor pada lembar observasi aktifitas peserta didik mengikuti pembelajaran mencapai 14,13 dengan skor tertinggi adala 15,00. Jika kualitatifkan menjadi kategori sangat tinggi .Berarti rata-rata peserta didik telah mengikuti pembelajaran dengan sangat baik. Motivasi peserta didik mengikuti pembelajaran juga lebih baik,

Berdasarkan data pada siklus III, Ketuntasan siswa masih tetap seperti siklus II yaitu 1 siswa yang belum tuntas, siswa tersebut tidak dipaksakan karena riwayat pendidikan di kelas sebelunya menunjukan mempunyai IQ di bawah rata-rata dan faktor gen dikeluarga juga mempengaruhi , tetapi motivasi siswa sudah meningkat secara signifikan yaitu semuala di siklus II pertemuan 2 yaitu 13,51 di siklus III pertemuan 2 mencapai 14,07 artinya peningkatan sudah maksimal menurut peneliti.

Sesuai dengan tujuan penelitian yang penulis lakukan, yaitu untuk meningkatkan motivasi dan peserta didik melalui pendekatan contextual teaching and learning, maka dalam pembahasan ini penulis membahas seputar peningkatan motivasi belajar peserta didik yang dicapai melalui perbaikan pembelajaran dalam dua siklus.

Penerapan pendekatan contextual teaching and learning telah berhasil meningkatkan motivasi belajar peserta didik padatema 3 subtema 1pembelajaran 3 sampai pembelajaran 6 . Peningkatan motivasi belajar peserta didik melalui pendekatan contextual teaching and learning dapat dilihat dengan membandingkan antara aktivitas peserta didik pada tindakan pra siklus, siklus I, siklus II, siklus III atas dapat disajikan dalam bentuk diagram batang sebagai berikut

\section{REKAPITULASI HASIL OBSERVASI MOTIVASI BELAJAR SISWA SEMUA SIKLUS}

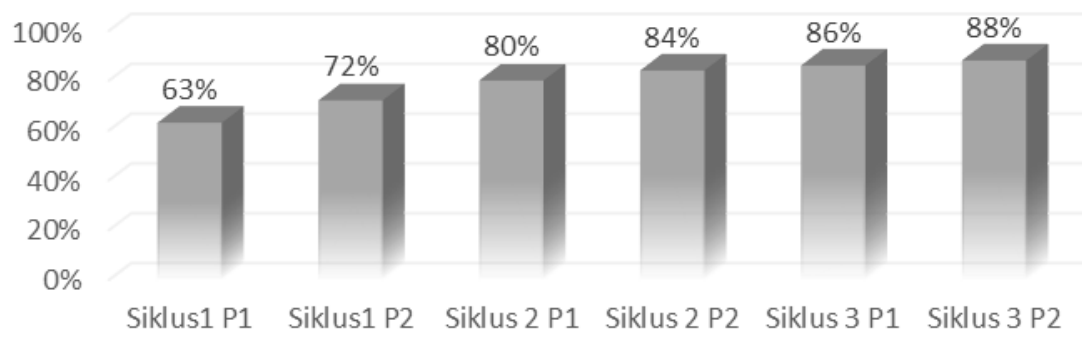




\section{Gambar 4.5. Rekapitulasi Hasil Observasi Motivasi Belajar Siklus I dan II, III}

Pembelajaran contextual teaching and learning dapat meningkatkan motivasi belajar siswa telah dilakukan penelitian 3 siklus. Implikasinya pada hasil belajar tentu ada peningkatan dari ketuntasan siswa dan nilai rata-rata setiap siklus selalu naik walaupun untuk siklus III ketuntasan tetap 1 siswa tidak tuntas tetapi untuk nilai ratarata kelas ada kenaikan di siklus III.

\section{SIMPULAN}

Dari seluruh data yang diperoleh dalam kegiatan perbaikan pembelajaran melalui penelitian tindakan kelas ini dengan penerapan pendekatan contextual teaching and learning,dapat diambil simpulan sebagai berikut: Penerapan pendekatan kontekstual dapat meningkatkan motivasi Belajar di kelas 3 SDN Wanoja 01. Hal ini ditandai dengan semakin berkualitasnya semangat dan respon siswa dalam memecahkan persoalan yang diberikan guru,meningkatnya kemampuan Komunikasi dan kerjasa siswa serta hasil belajar yang diperoleh siswa. Peningkatan tersebut meliputi : (a) meningkatnya kerjasama siswa dan tolong menolong antar siswa untuk memecahkan soal dalam proses pembelajaran (b) meningkatnya kekompakan antarsiswa (c) meningkatnya keterlibatan siswa dalam proses pembelajaran. Pembelajaran kontekstual, telah memberikan nuansa baru dalam pembelajaran di tema 3 sehingga pembelajaran lebih efektif. Hal ini terbukti dengan adanya perubahan yang signifikan terhadap ketuntasan belajar siswa. Dengan pendekatan kontekstual guru mendapatkan kemudahan dalam berkreasi dan berinovasi, lebih efektif dan efisien waktu untuk mencapai tujuan pembelajaran, berfikir secara efektif dalam menyelesaikan masalah sederhana

\section{DAFTAR PUSTAKA}

Arikunto, S., Cepi. 2010. Evaluasi Program Pendidikan. Jakarta: Bumi Aksara

Arikunto, S., Suhardjono, dan Supardi. 2010. Penelitian Tindakan Kelas. Jakarta: Bumi Aksara

Djamarah. 2005. Guru dan Anak Didik dalam Interaksi Edukatif Suatu Pendekatan Teoritis Psikologis. Jakarta: PT Rineka Cipta.

Purwanto, M.N. 2010. Prinsip-Prinsip dan Teknik Evaluasi Pengajaran. Bandung: PT Remaja Rosdakarya.

Slameto. 2010. Belajar dan Faktor-Faktor yang Mempengaruhinya. Jakarta: Rineka Cipta.

Sudjana, N. 2001. Penilaian Hasil Proses Belajar Mengajar. Bandung: PT Remaja Rosdakarya.

Sudjana, N. 2008. Dasar-Dasar Proses Belajar Mengajar. Bandung: Sinar Baru Algensindo.

(http://blog.unnes.ac.id/ayukwitantri/2016/02/12pengertian-sejarah-dan-fungsimicrosoft-powerpoint-beserta-kelebihannya/ diunduh pada hari Senin, tanggal 12 Oktober 2020 pukul 22.11 WIB)

(https://www.materi.carageo.com/pengertian-video/ diunduh pada hari Selasa, tanggal 13 Oktober 2020 pukul 05.56)

Kemendikbud. 2018. Buku Tematik Terpadu Kurikulum 2013 Tema 3 Benda Disekitarku Kelas 3. Jakarta: Pusat Kurikulum dan Perbukuan, Balitbang Kemendikbud 
SHEs: Conference Series 3 (3) (2020) 48- 56

Rahmawati N Dwiki. 2018. Buku Tematik Terpadu Kurikulum 2013 Tema 3 Benda Disekitarku Kelas 3.Klaten: Grafika Dua Tujuh

Jurnal Penelitian Guru Indonesia - JPGI (2016) Vol 1 No 1 Print ISSN: 2541-3163 Online ISSN: 2541-3317) 